\title{
MONETARY POLICY AND THE 2007-08 GLOBAL FINANCIAL CRISIS: AN OVERVIEW
}

\section{Mete Han YAĞMUR*}

\begin{abstract}
This paper analyzes the run up of the financial crisis from monetary policy point of view. After showing that the Taylor rule closely conforms to policy interest rate setting practices of the Federal Reserve System (Fed) from 1987 onwards, we use the Taylor rule in order to represent the Fed's interest rate setting policy. Utilizing cumulative sum (cusum) and Chow forecast tests we show that starting from the early 2000s the Fed started to follow a loose monetary policy. We argue that loose monetary policy and the consequent excess liquidity in the markets, accompanied by easy credit policies and deregulation in the financial system helped to fledge a housing bubble and hence the 2007-08 global financial crisis. We also discuss unconventional monetary policies during the crisis period and the desire of the Fed to return to normal time policies as the economic situation improves.
\end{abstract}

Keywords: Monetary Policy, Taylor Rule, Global Financial Crisis

Jel Codes: E52, E58, G01

\section{PARA POLITTIKASI VE 2007-2008 KÜRESEL FINANSAL KRİZİ: GENEL BİR DEĞERLENDİRME}

Öz

$\mathrm{Bu}$ çalışma küresel finansal krize giden süreçte Amerika Merkez Bankası’nın (Fed) izlediği para politikasını incelemiştir. Taylor kanununun Fed'in politika faiz oranlarını belirlemesini başarılı bir şekilde açıkladığını gösterdikten sonra Taylor kanununu para politikası analizimiz için kullandık. Krize giden süreçte Fed'in politikalarında bir kırılma olup olmadığını ardışık kalıntılar toplamı (cusum) ve Chow testleriyle sınadık. Test sonuçları bize 2003 yılından itibaren Fed'in genişleyici bir para politikası takip ettiğini gösterdi. Bu çalışmada, genişleyici para politikası ve likidite bolluğuna eşlik eden bankaların kolay

* Arş. Gör. İstanbul Ticaret Üniversitesi, Ticari Bilimler Fakültesi, İng. İktisat Bölümü.

myagmur@ticaret.edu.tr 
kredi verme politikalarının bir konut balonuna ve nihayetinde 2007-08 küresel finansal krizine yol açtığı tartışıldı. Son olarak da, kriz boyunca takip edilen geleneksel olmayan para politikalarından ve geleneksel para politikalarına dönme eğiliminden bahsedildi.

Anahtar Kelimeler: Para Politikası, Taylor Kanunu, Küresel Finansal Kriz

Jel Kodları: E52, E58, G01

\section{Introduction}

The global financial crisis that started in the US in 2007-08 and shook up the global economic and financial system was actually preceded by a two decades long tranquil period: the great moderation. From the early 1980s the US (and to some extent other developed countries) experienced a more steady real GDP growth and low and stable inflation. For instance, in order to identify this era (Stock and Watson 2003, 6) measure the standard deviation of growth of GDP (averaged four quarters), and find out that it is one third less during 1984 to 2002 than it is during 1960 to 1983.

There are different views about what had generated the great moderation. (Stock and Watson 2003 ,3) suggest that much of the drop in output and inflation volatility was due to smaller macroeconomic shocks (such as oil price shocks or productivity shocks) in this period. (Davis and Kahn 2008, 1-2) suggest that improved inventory control (supported by technological advances) is a major contributor to the decline in US aggregate output volatility. (Clarida, Gali and Gertler, $2000,148)$ suggest that better monetary policies during this period resulted in reduced inflation and output volatility. In order to underline this point the authors state that lack of macroeconomic shocks may also be effective in bringing about stable output growth; but better monetary policy making practices is necessary to generate steady low inflation.

As better monetary policies are considered to be a major source of the great moderation, deviation from good monetary policy making turns out to be the major factor that ended the great moderation as well as the driving force of the 2007-08 global financial crisis. This paper analyzes the run up of the financial crisis from monetary policy point of view. Specifically, we argue that starting from the early 2000s the Federal Reserve System (Fed) started to follow loose monetary policies and provided the markets with superfluous liquidity. The excess liquidity in return damaged the stability of the financial markets and called forth the financial crisis. Excess liquidity combined with easy credit policies and financial deregulation triggered the 2007-08 financial crisis.

More specifically, accompanied with easy access to home loans, loose monetary policy first helped to inflate the housing prices in the US. When the Fed started increasing its policy interest rates (due to inflationary pressures) the housing bubble eventually burst. Thence, it was realized that improvements in financial products during the past few decades and regulators' 
failure to keep pace with financial innovation left the financial system vulnerable to shocks. Accordingly, after the burst of the housing bubble many of the world's largest banks were caught with dangerously low capitalization which was far from sufficient to absorb the losses that the banks had to undertake. In return, mistrust in the financial markets led to panic and bank runs. Even some of the biggest global financial institutions either failed, bought by some other banks or taken over by government.

Despite its importance and role in the financial crisis, this paper does not analyze the financial regulation (or, deregulation) in depth. We rather intend to reveal the loose monetary policy practices in the run up of the crisis. In order to do so, we first show that, in normal times, the Taylor rule represents the Fed's (as well as many other central banks') interest rate setting practices quite well. Afterwards, we show that the Fed diverged from the Taylor rule and moved towards a lax monetary policy starting from early 2000s. And we argue that, combined with financial deregulation, loose monetary policy followed in this period led to financial crisis.

The paper is organized as follows. The following section starts with monetary policy analysis and the Taylor rule. Section 3 empirically shows the divergence from the Taylor rule and the emergence of the financial crisis. Section 4 briefly discusses the transmission of lose monetary policies to housing bubble and the unconventional monetary policy making during the crisis. The last section concludes.

\section{Monetary Policy and the Taylor Rule}

During the past few decades there has been a substantial progress in monetary theory and a wide consensus on characteristics of good monetary policy making has emerged. For instance, there is an agreement on the necessity of central bank (CB) independence for good monetary policy performance. Or, for the general course of monetary policy many central banks today set price stability as their primary objective and they follow inflation targeting (IT) in order to maintain this objective. Maintaining maximum attainable level of employment is the other goal that major $\mathrm{CBs}$ assume. For instance, the Fed has a dual mandate of maintaining price stability and attaining a maximum level of employment. The Bank of England's (BOE) core objective is price stability but the bank stresses that low inflation is not an end itself; according to the BOE it is a precondition for achieving sustainable growth and a high level of employment.

On the theoretical side, many CBs have adopted New Keynesian (NK) model as the main frame of their medium-scale models. The NK framework incorporates imperfect competition and staggered price adjustment into macroeconomic framework where rational agents solve intertemporal optimization problems. More specifically, supply side of the NK model is composed of monopolistically competitive firms and Calvo type price or wage stickiness. On the demand side, Euler equation determines optimal intertemporal consumption allocation and a Taylor type interest rate rule determines policy interest rates (Blanchard and Gali, 2007, 35). Hence, monetary policy in the NK model is represented by a Taylor rule. 


\section{I. The Taylor Rule}

In his seminal paper, (Taylor 1993, 202) shows that the Fed interest rate setting policy can be described by adjustments in its policy interest rates in response to deviation of inflation from a target level and deviation of output from its natural level. This simple rule is actually composed of the two targets (or the dual mandate) of the Fed: maximum sustainable economic growth (or employment) and price level stability. The corresponding simple monetary policy specification reads:

$$
i_{t}=r+\pi_{t}+g_{\pi} \bar{\pi}_{t}+g_{y} \bar{y}_{t}+\varepsilon_{t},
$$

where, is the policy interest rate; is the neutral real interest rate; is the inflation rate; is the deviation of inflation from its target level; is deviation of output from its natural level; and is stochastic error term. (Taylor, 1993, 202) assumes that the neutral real rate to be $2 \%{ }^{1}$ uses CPI as inflation measure and takes the average CPI over the past four quarters in order to get a smoothed inflation measure. Target inflation rate is assumed to be $2 \%$; this is also the official inflation target that the Fed set in 2012.

In the underlying loss function, the Fed minimizes the deviation of inflation from its target level and deviation of output from its natural level as in the following form:

$$
\min \frac{1}{2} \gamma\left(\pi-\pi^{*}\right)^{2}+\frac{1}{2}\left(y-y_{n}\right)^{2}
$$

where is the target level of inflation and is the natural level of output. ${ }^{2}$

(Taylor, 1993, 202) tests the above simple interest rate rule with coefficients and for the 1987-1992 period and shows that this rule closely corresponds to the Fed's policy interest rates. We have re-calculated the Taylor rule with coefficients as in (Taylor, 1993, 202) for the period 1987-2007. Figure 1 below is a generic comparison of the Taylor rule with the Fed rates in this period.

1 Average real interest rate over an appropriate period is considered to be a good proxy for the neutral real interest rate.

2 (Rotemberg and Woodford, 1999, 73) show that such a loss function may be obtained by quadratic approximation of a utility based welfare function, where households derive disutility from deviations from the efficient allocation. Nevertheless, as (Woodford, 2003, 618) puts forward, despite the fact that Taylor rule has some characteristics of reaction function associated with optimal policies and in spite of its usefulness, Taylor type of rules are not substitutes for fully-fledged economic models. 
Figure I. The Taylor Rule and the Fed Rates, Quarterly US Data

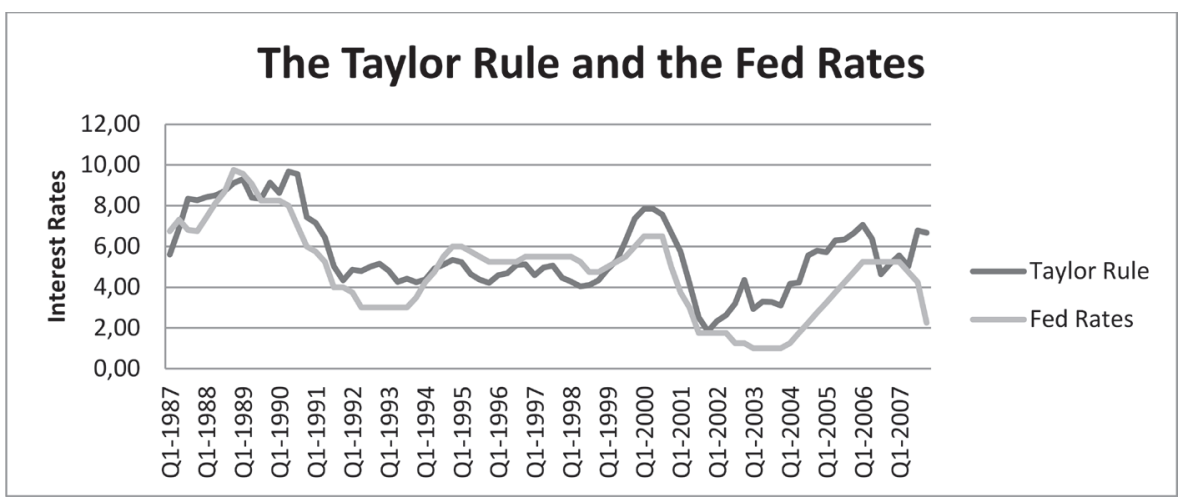

Data Source: Federal Reserve Bank of St. Louis and Bureau of Labor Statistics. Authors own calculation.

The success of the Taylor rule in matching the Fed's policy interest rates, its strength as a feedback rule in improving decision making process of policy makers, and its ease of use endowed the Taylor rule to emerge as a common characterization of the Fed's and many other major central banks' interest rate setting behavior. Consequently, many scholars utilized the Taylor rule in their monetary policy analysis. For instance, using a Taylor type of rule, (Clarida, Gali and Gertler, 2000, 155-156) study the conduct of monetary policy under different Fed chairs and the authors find substantial differences between pre and post 1979 periods. Specifically, the authors show that prior to 1979, in response to increases in expected inflation the Fed increased its (nominal) policy interest rates by less than the increases in expected inflation; in other words, the monetary policy was accommodative during this period. In the post-1979 period, the authors show, the Fed increased its nominal as well as real policy interest rates in response to increases in expected inflation; hence, the monetary policy was anti-inflationary and stabilizing in this period.

In (Clarida, Gali and Gertler, 1998, 1042-1061) the authors again utilize a Taylor type rule to provide an insight for interest rate setting behaviors of G3 (Germany, Japan, US) and E3 (the UK, France and Italy) countries. The authors study the G3 countries in the post-1979 era in order to identify the features of effective monetary policy making; and they analyze the E3 countries in order to identify the problems of monetary policy making during the European Monetary System (EMS) era, which collapsed in late 1992.

(Adam, Cobham and Girardin, 2005, 497-516) estimate reaction function of Bank of England (BOE) based on augmented Taylor rule in three sub periods: pre-European Exchange Rate Mechanism (ERM) (1985-1990), post-ERM (after 1992) and the period when BOE was given operational independence (in 1997). Results of the study suggest that institutional arrangements are decisive on policy reaction functions; BOE started to follow reaction functions similar to other developed countries' central banks (like those of G3) only after it gained operational 
independence. Likewise, (Nelson, 2000, 7-29) and (Taylor and Davradakis, 2006, 2-11) also apply the Taylor rule to study the UK monetary policy. (Demers and Rodrigues, 2002, 1-13) study the Canadian interest rate setting behavior within a Taylor rule framework.

Despite the success of the Taylor rule in predicting the Fed's (and other CBs') policy interest rates, empirical studies show that $\mathrm{CBs}$ ' tend to move their interest rates gradually. However, (Rudebusch, 2002, 1161-1187) and (Rudebusch and Wu, 2008, 906-926) show that interest rate changes cannot be predicted in the financial markets; the authors accordingly conclude that there is no deliberate interest rate smoothing. Following this argument, we do not utilize an interest rate smoothing term in our analysis and employ a Taylor rule in its original form.

\section{Empirical Analysis}

A crucial point to be observed in Figure 1 above is that the Fed's policy interest rates persistently remained below what the Taylor rule suggests during the few years prior to 2007 . More specifically, if one takes the interest rates implied by the Taylor rule as a basis, from around 2002 onwards the Fed maintained a loose monetary policy. In order to test the validity of this argument we first run an OLS regression and identify the Taylor rule coefficients. Afterwards we investigate whether if there was a structural break in the Fed policies prior to crisis.

The Taylor rule we utilize is a standard one as in equation (1) above. Specifically:

$$
\text { Fed } \text { Rates }_{t}=\beta_{0}+\beta_{1} * \text { outputgap }_{t}+\beta_{2} *\left(\text { inf }_{t}-2\right)+\varepsilon_{t}
$$

The intercept coefficient, , by nature is composed of neutral interest rate and inflation rate. This is actually the fictive Fed rate when output gap is zero and inflation is at its $2 \%$ target rate.

\section{Data}

There has been some controversy on whether to use past data or forecast variables in Taylor rule analysis. (Taylor, 1993, 202) uses lagged values of inflation for his analysis and states that lagged inflation rate serves as a proxy for expected inflation. (Taylor, 2009, 345) shows that, regarding the impacts of policy rules there is not much difference between using inflation forecasts and using past variables. Similarly, (Clarida, Gali and Gertler, 2000, 151) consider forward looking specifications to be more plausible in their monetary policy analysis, but the authors show that their key results hold also with backward looking specifications. Moreover, (Woodford, 2003, 617) shows that both contemporaneous and lagged variables could be used to specify an optimal

rule. The author argues that as long as the Taylor rule is interpreted as a feedback rule to achieve 
a desirable path for target variables it may be considered in the set of optimal policy analysis. Following these arguments, we adopt original Taylor rule specification and use contemporaneous and lagged data (rather than expectations) in our analysis.

In order to conform to the literature, in particular to the original work of (Taylor, 1993, 202), we use quarterly data and our data starts from 1987. Because crisis periods are not suitable for long term monetary policy analysis and because unconventional monetary policies came into effect in 2008, December 2007 marks the end date of our analysis.

The Fed states that while setting its policy interest rates the monetary policy committee considers inflation over some periods (ranging from a few months to a year). This is because, the Fed argues, inflation level can widely vary from month to month. Following the Fed's practice and (Taylor, 1993, 202) we use smoothed values of inflation over the past four quarters to set the deviation of inflation from its target level. Quarterly CPI data is extracted from US Department of Labor: Bureau of Labor Statistics.

We derived output gap using Industrial Production Index (IPI) by HP-filtering method. Both the IPI data and Federal Funds Target Rate is extracted from Board of Governors of the Federal Reserve System. All the results are produced by E-views.

\section{Results}

The OLS output for equation (3) for the period 1987-2007 is as follows; the standard error of each regression coefficient is given in parenthesis. ${ }^{3}$

$$
\begin{array}{r}
\text { Fed } \text { Rates }_{t}=3.48+0.74\left(\text { outputgap }_{t}\right)+1.2\left(\text { inf }_{t}-2\right) \\
\left(R^{2}\right)=0.7 \quad(0.07)
\end{array}
$$

The coefficient estimates are all significant and correctly signed. Being greater than one, the inflation coefficient also satisfies the "Taylor principle" which states that for rational expectations model of this type of model to be stable, interest rate increases should be greater than the rise in inflation. The OLS output is in accordance with our expectations as well as with the Fed rates as depicted in Figure 2 below.

3 Stationarity of Fed rates, outputgap and inflation are tested with Ng-Perron (both with 'trend' and 'trend and intercept' options). Presence of unit root is rejected at 5\% significance level in all the cases. 
Figure 2. (OLS) Estimated Taylor Rule and the Fed Rates, Quarterly US Data

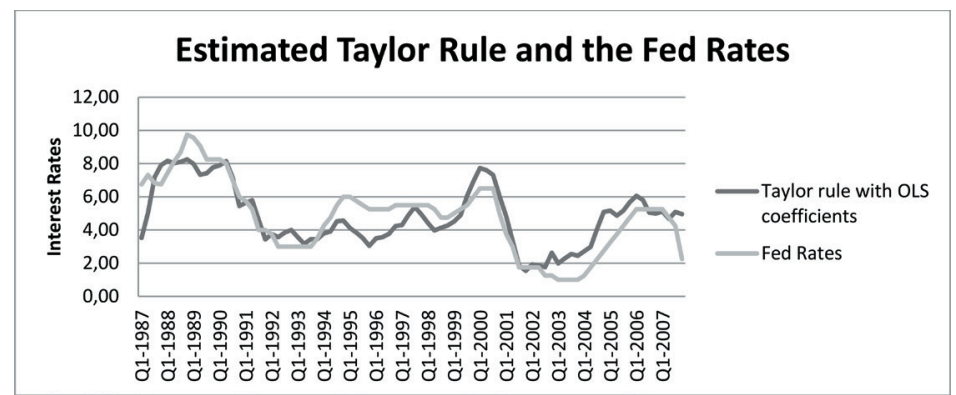

Data Source: Federal Reserve Bank of St. Louis and U.S Bureau of Labor Statistics. Authors own calculation.

We now turn to analyze whether if there was a structural break in the Fed policies before the crisis. That is, we would like to see if the Fed started to follow a loose monetary policy in the run up of the crisis. Initially, we would like to see if there is any indication of structural break in the implied monetary policy making of the Fed. (Brown, Durbin and Evans, 1975, 153) propose to calculate cumulative sum (CUSUM) of the recursive forecast errors in order to identify gradual changes in a model. Formally,

$$
\operatorname{CUSUM}_{N}=\sum_{i=1}^{N} \frac{\varepsilon_{i}(1)}{\sigma_{\varepsilon}} \quad N=n, \ldots, T-1
$$

where, $\mathrm{n}$ is the date of the first forecast error, $\mathrm{T}$ is the last observation in the data set, and is the standard deviation of the forecast errors.

If CUSUM is statistically different from zero the procedure implies a structural break in the model. The CUSUM analysis of our model, with 5\% significance level is given below. Figure 3 indicates that starting from 2001 there is a gradual change in our model. ${ }^{4}$

Figure 3. CUSUM Analysis for Parameter Stability.

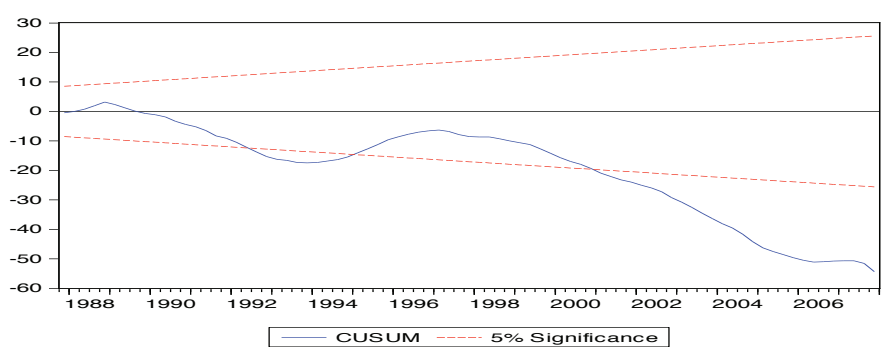

4 An event like breakdown of the Bretton Woods System or the Exchange Rate Mechanism would indicate a discrete (rather than gradual) change. 
The CUSUM analysis provides a good reason to suspect a structural break in our model. To be more concrete, we now run a Chow forecast test in order to see if our model is sufficiently different during 1987-2002 and during 2003-2007 periods. The null hypothesis of the Chow forecast tests is that there is no structural change in the equation over the sample period. The test results are given below.

Table I. Chow Forecast Test Results

Chow Forecast Test

Equation: TAYLOR

Specification: FEDRATES $=\mathrm{C}(1)+\mathrm{C}(2)^{\star} \mathrm{OUTPUTGAP}+\mathrm{C}(3)^{\star}(\mathrm{AVGCPI}-2)$

Test predictions for observations from 2003Q1 to 2007Q4

F-statistic

Likelihood ratio

\begin{tabular}{lll} 
Value & df & Probability \\
\hline 2.040887 & $(20,61)$ & 0.0174 \\
43.03407 & 20 & 0.0020 \\
\hline
\end{tabular}

Both the F-statistics and the likelihood ratio statistics reject the null hypothesis that there is no structural change in the interest rate setting function before and after 2003. Hence, at 5\% significance level both the CUSUM test and the Chow forecast tests indicates a structural break in the Taylor rule indicated Fed policies around 2003.

As the two tests that we have run above indicate a structural break around 2003, we generated dummy variables with zeros for the period 1987 to 2003 and ones from 2003 onwards and re-run the OLS regression. The coefficients of the Taylor rule with dummy variables are given below; the standard error of each regression coefficient is given in parenthesis.

$$
\begin{aligned}
& \text { Fed } \text { Rates }_{t}=3.91+0.71\left(\text { outputgap }_{t}\right)+1.12\left(\text { inf }_{t}-2\right)-1.44(\text { dummy }) \\
& \left(R^{2}=0.79\right) \\
& \text { (0.17) (0.06) } \\
& \text { (0.11) } \\
& (0.25)
\end{aligned}
$$

The regression results indicate that the Fed rates from 2003 to 2007 were 1.44 points lower compared to the period 1987-2003. Hence, our findings are in accordance with the arguments that the Fed was following extra loose monetary policy prior to crisis which eventually turned out to be a major source of the financial crisis.

Nevertheless, the Fed's chairman at the time, Ben Bernanke objects to these criticism. (Bernanke, 2010, 8) argues that, the Fed uses inflation forecasts (rather than the past inflation rates used in the standard Taylor rule) and their feedback rule is in line with their inflation expectations. It is also argued that the Fed kept its policy interest rates at low levels in order 
to mitigate the effects of the dot-com bubble that burst in early 2000s. Or, Fed's aversion for deflation (witnessing decades long Japanese trouble) might also have played a role in its low interest rate policies. Some scholars also argue that it was rather the "savings glut" in Asia that kept global interest rates low. But in any case, the Fed's expected inflation rate turns out to be too low in order to maintain a stable monetary policy.

\section{Loose Monetary Policy and the Crisis: The Transmission Mechanism}

Prolonged loose monetary policy often jeopardizes financial stability. Regarding the 20072008 financial crisis, (Taylor, 2009, 342) argues that monetary excesses were the main cause of the housing boom; and the bust of the housing market was the driving force of the financial turmoil. As we have showed above, the Fed indeed followed extraordinary loose monetary policy in the run up of the 2007-2008 financial crisis. Low policy interest rates, together with easy credit policies, induced a housing bubble. Specifically, starting from early 2000s easy credit policies and loose monetary policy made mortgages attractive to many households and fostered demand for housing. The figure below depicts the extraordinary escalation in the house prices starting from early 2003, and the peak around 2006. Note that the rise in house prices coincides with the extra expansionary monetary policy period indicated above.

Figure 4. Median Sales Prices for New Houses Sold in the United States.

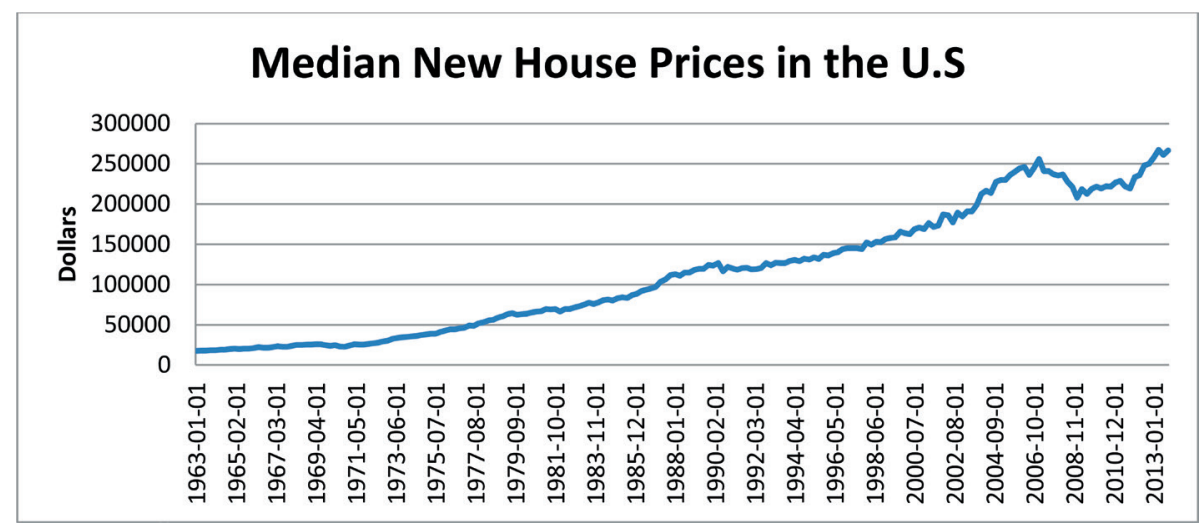

Source: Data from Federal Reserve Bank of St. Louis.

Studying the role of housing market and monetary policy in the US business cycles (Jarocinski and Smets, 2008, 16) find that easy monetary policy had contributed to the housing market boom in 2004 and 2005. (Ahrend, Cournede and Price, 2008, 5) also find that periods in which short term interest rates remain below what the Taylor rule suggests are generally correlated with imbalances in housing markets. 
Regarding the effect of monetary policy on easy credit policies, (Jimenez, Ongena, Peydro and Saurina, 2014, 463-505) find that lower policy interest rates induce banks to expand credit to riskier agents. Indeed, as interest rates remained low, banks extended mortgage credits to households with poor credit histories (or "subprime" borrowers). As house prices started to plunge in late 2006, subprime mortgage borrowers started to default and financial institutions that held subprime mortgages started announcing losses. The subsequent spread and deepening of the crisis was further engineered in the shadow banking system (i.e., financial institutions like investment banking and the hedge funds), where financial deregulation was more apparent. These financial institutions took over some mortgage loans, pooled them and created mortgage backed securities (MBS) and sold them in the global financial market. MBS' were imagined to be low-risk securities. However, as the housing market in the US crashed on a nationwide basis, it was realized that MBS' were no safer than the subprime mortgages. Accordingly, even determining the worth of MBS' became a challenge and financial institutions' balance sheets and their stance were under suspicion. In sum, loose monetary policy, easy credit policies and financial deregulation generated financial instability and new financial instruments helped to spread the crisis to a global basis.

\section{I. Unconventional Monetary Policy during the Crisis}

When the U.S government seized two government sponsored agencies that provide funding for new home mortgages, Fannie Mae and Freddie Mac, the instability in the financial sector was deepened. Panic in the world financial system started when Lehman Brothers collapsed in September 2008. Takeover of Bank of America by Meryl Lynch and bailout package in order to rescue AIG were the aftershocks to the global financial system and to the world economy.

Following the crisis in the financial sector, the US economy started sliding into a deep recession. Fed's first reaction was cutting the policy interest rates up to the zero lower bound. But in order to prevent a recession like the one in 1930s the Fed still had to provide stimulus to the economy. Hence, unconventional monetary policies came into effect. Extra ordinary forward guidance and quantitative easing (QE) turned out to be the two major policies that the Fed, as well as some other central banks, has been following since then. Forward guidance is explicit and stronger policy communication with the public. During the crisis central bankers promised to keep interest rates at low levels for extended period of time in order to influence people's expectations of future interest rates and economic activities.

QE is large scale (mostly long-term) asset purchase program with newly printed money. The Fed's asset purchases mostly composed of mortgage backed securities and Treasury bills. As QE increases the demand for assets, long term interest rates decrease and in return, economic recovery is supported thru monetary policy. The following figure exhibits the dramatic increase in the Fed's total assets following the financial crisis. Prior to crisis, Fed's total assets were less than 1 trillion dollar; by 2014 total value of assets exceeded 4 trillion dollars. 
Figure 5. Total Assets of the Federal Reserve System.

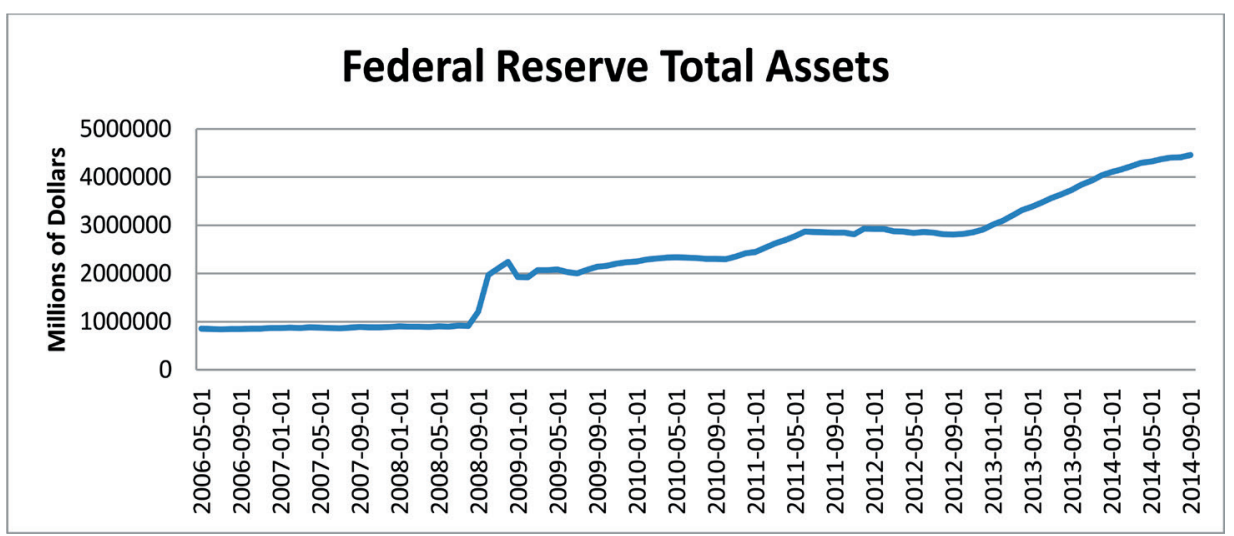

Source: Data from Federal Reserve Bank of St. Louis

There have been 3 rounds of QE in the US, each with different targets in economic recovery. QE1 mainly targeted the banking sector. The banking sector turned out to be highly fragile in the aftermath of the crisis; the sector was impeding economic recovery because banks were not willing to provide credit to the economic agents. Starting from November 2008, for 17 months the Fed purchased \$1.7 trillion worth of securities, which 1.25 trillion of it was mortgage backed securities. In return, the Fed cleared banks' balance sheets from their toxic subprime securities and helped the banking sector to recover.

QE2 started in November 2010 and for 7 months the Fed purchased $\$ 85$ billion of Treasury bills each month to support the economic activity. In September 2011 the Fed revised QE2 thru a program called "operation twist". According to this program the Fed used its proceedings from matured short-term Treasury bills to buy long term Treasury bills. The program also included matured short term mortgage backed securities to buy longer term mortgage backed securities. The purpose of this program was to support the housing market.

Finally, the Fed announced QE3 in September 2012. With QE3 the Fed promised to purchase $\$ 85$ billion of assets each month, which also included operation twist. In addition to asset purchases, the Fed announced that it would keep Fed fund rates at zero until 2015 and would continue to buy bonds until the job market improves "substantially". This promise also clarifies the target of QE3: to boost economic activity. These announcements were also part of the forward guidance; intending to influence long-term interest rates by informing the public about the future course of monetary policy.

The Fed was not the only central bank that used quantitative easing but together with the Bank of England (BOE), it was the boldest one in this respect. European Central Bank (ECB) also made some form of asset purchases in order to overcome the financial crisis. However, as shown in Figure 6 below, compared to the Fed and the BOE, the ECB was rather slow or hesitant to 
expand its balance sheet. Europe's recovery from recession was also slow compared to the US and the UK. Specifically, while the US's and the UK's growth rates are 5.9 and 6.2, respectively, in the second quarter of 2014; Eurozone economy could grow only $0.7 \%$ in the same period. Likewise, while the unemployment rate in the US and the UK is around 6\%; it is 11.5\% in the Euro area. Some scholars witness the strong and faster recovery of the US and the UK from the crisis as the success of bolder monetary policies (in particular the QE). ${ }^{5}$

Figure 6. Total Assets of the Federal Reserve, Bank of England and European Central Bank.

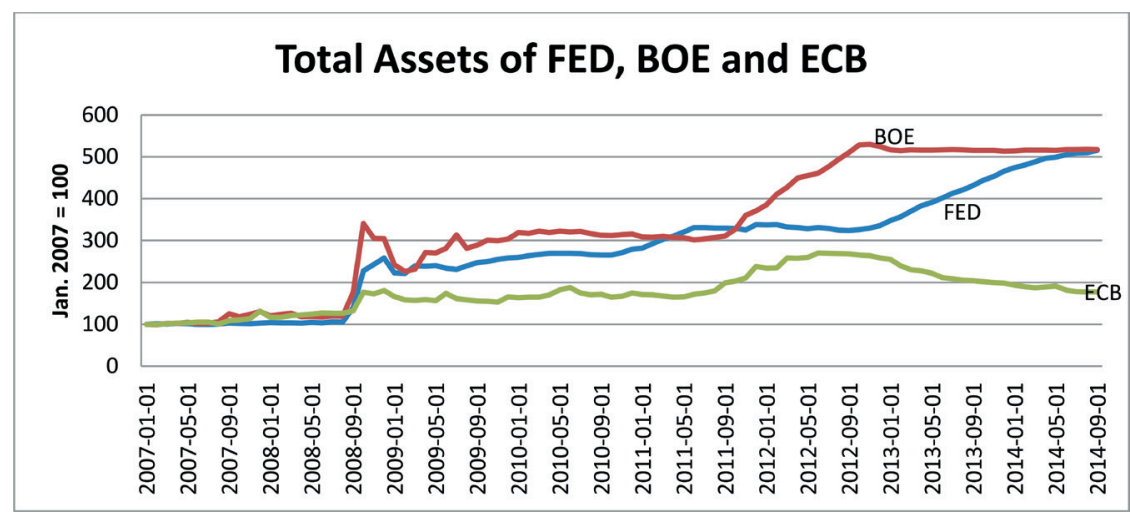

Source: Data from Federal Reserve Bank of St. Louis.

\subsection{Exit from Unconventional Monetary Policies}

In order to specify its exit plan from the QE, the FED announced in December 2012 that it would continue with its $\$ 85$ billion worth of monthly asset purchases until either the core inflation rises above $2.5 \%$ or unemployment falls below $6.5 \%{ }^{6}$ Such clear targets improved public communication of monetary policy. And in December 2013, the Fed announced that it would reduce its asset purchases by $\$ 10$ billion monthly. The Fed kept on reducing its asset purchases gradually and finally in October 2014 the Fed announced that it has ended its asset purchases program.

(Gertler and Karadi, 2011, 6-50) develop and a DSGE model in order to analyze unconventional monetary policy in the manner that the Fed had followed during the financial crisis. The authors show that central bank intermediation is effective especially when the zero lower bound starts to bind. Nevertheless, taking the "politicization of credit allocation" into account, the authors argue

5 In addition to monetary policies, the US Treasury also applied some expansionary fiscal policies in order to stimulate demand; but they were limited in scope and in effect.

6 Later on, the Fed announced that even after these thresholds are reached they would not be considered as automatic triggers. 
that unconventional monetary policies should be reserved for crisis times only. (Bean, Paustian, Penalver and Taylor, 2010, 1-27) argue that if applied in normal times, policies such as the QE would distort the market structure. Accordingly, the authors suggest that, $\mathrm{CBs}$ should return to short term policy interest rate management as their aggregate demand management tool.

Hence, despite the fact that unconventional monetary policies during the crisis helped to mitigate the effects of the crisis, the research suggest that these policies are not well-suited for normal time policy making. Fed's exit from the asset purchasing program and its announcement that it will start increasing its policy interest rates after unemployment level falls to $6.5 \%$ or annual inflation rate rises to $2.5 \%$ implies the Fed's desire to end crisis time policies and again let the main economic indicators to determine the structure of monetary policy.

\section{Conclusion}

In this paper we have argued that good monetary policy making practices played a key role in achieving an era of low and stable inflation and steady output growth levels, so called the great moderation. We have also argued that deviation from the fundamentals of good monetary policies and following expansionary policies for extended period of time brought an end to the great moderation era and contributed to the emergence of the 2007-08 global financial crisis.

For monetary policy analysis we have employed the Taylor rule due to its efficiency as a feedback rule and due to its practicality in policy analysis. Using a simple OLS regression we first showed that the Taylor rule represents the Fed's interest rate setting behavior quite well. Afterwards, in order to detect the structural break in Fed's policies prior to crisis we performed CUSUM and Chow forecast tests. These tests confirmed our suspicion about the gradual break in the Fed policies; and the policy interest rates lower than the ones indicated by the Taylor rule confirmed the loose monetary policies starting from the early 2000s.

The period of lax monetary policy and excessive liquidity led to housing bubble, whose burst marked beginning of the financial crisis. After the burst of the housing bubble, it was realized that the financial system was weaker than it was imagined due to deregulations in the system during the past few decades.

Regarding the Fed's reaction to the global financial crisis we have argued that the Fed first responded to the crisis by decreasing its policy interest rates. But as the zero lower bound started to bite the economy was still sliding into deeper recession due to weak financial system. In return, the Fed started to carry out unconventional monetary policies, such as quantitative easing and forward guidance. Other major central banks, such as the BOE, BOJ, and ECB also followed similar unconventional monetary policies. It is usually agreed upon that these policies prevented a complete financial collapse and helped the global economy to recover from the crisis.

Despite their usefulness during the crisis times, studies show that unconventional policies should be reserved only for extraordinary times. We observe that the Fed is also adjusting its policies in this direction. In May 2013 the Fed declared that it would decrease its monthly asset 
purchases as the economic conditions improve. As a next step, the Fed announced, it would start increasing its policy interest rates from around its zero level as unemployment and inflation levels reach to certain levels. Indeed, quitting the QE and letting inflation and unemployment levels determine its policy interest rates means turning back to its normal time policies.

Getting back on the pre-crisis policy practices should be no surprise as both the basics of good monetary policy making and consequences of deviation from these policies have been apprehended. As the great moderation era taught the basics of good monetary policy making; the global financial crisis have taught the dangers of deviation from those policies. 


\section{References}

ADAM, C., COBHAM, D. and GIRARDIN, E. 2005. "Monetary frameworks and institutional constraints: UK monetary policy reaction functions, 1985-2003” Oxford Bulletin of Economics and Statistics, 67 (4), pp. 497-516

AHREND, R., B. COURNEDE and R. W. PRICE (2008). "Monetary Policy, Market Excesses and Financial Turmoil”, OECD Economic Department WP, No. 597

BEAN, C., PAUSTIAN, M., PENALVER, A. and TAYLOR, T. 2010. "Monetary policy after the fall" BIS Review 111/2010

BERNANKE, Ben S. 2010. "Monetary Policy and the Housing Bubble" Annual Meeting of the American Economic Association. Atlanta, Georgia.

BLANCHARD, Oliver and GALI, Jordi. 2007. "Real wage rigidities and the New Keynesian model” Journal of Money Credit and Banking, Vol. 39, No. 1

BROWN, R. L, DURBIN, J., EVANS, J. M. 1975. "Techniques for testing the constancy of regression relationships over time" Journal of Royal Statistical Society Series. Series B (Methodological) Vol. 37, No.2 pp.149-192

CLARIDA, R., GALI, J., GERTLER, M., 1998 "Monetary policy rules in practice, some international evidence" European Economic Review 42, pp. 1033-1067

CLARIDA, R., GALI, J., GERTLER, M., 2000. "Monetary policy rules and macroeconomic stability: Evidence and some theory" Quarterly Journal of Economics 115, pp. 147-180

DAVIS, Steven J. and KAHN, James A. 2008 "Interpreting the great moderation: Changes in the volatility of economic activity at the macro and micro levels" NBER WP No. 14048

DEMERS, Frederick and RODRIGUES, Gabriel, 2002. "Estimation of the Taylor rule for Canada under multiple structural changes" University of Ottawa WP 0107E

GERTLER, Mark and KARADI, Peter. 2011. "A model of unconventional monetary policy" Journal of Monetary Economics 58, pp.17-34

JAROCINSKI, Marek and SMETS, Frank, 2008. "House Prices and Stance of Monetary Policy" 32nd Annual Economic Policy Conference of the Federal Reserve Bank of St. Louis on "Monetary Policy under Uncertainty"

JIMENEZ, G., ONGENA, S., PEYDRO, J., SAURINA, J., 2014. "Hazardous Times for Monetary Policy: What Do Twenty-Three Million Bank Loans Say About the Effects of Monetary Policy on Credit Risk-Taking?” Econometrica, 82,2 pp. 463-505.

NELSON, Edward 2000. "UK monetary policy 1972-97: a guide using Taylor rules" Bank of England Working Paper

ROTEMBERG, Julio, and WOODFORD, Michael 1999. "Interest rate rules in an estimated sticky price model” in J. B. Taylor (ed.), Monetary Policy Rules, University of Chicago Press, Chicago, IL.

RUDEBUSCH, Glenn D 2002. “Term structure evidence on interest rate smoothing and monetary policy inertia” Journal of Monetary Economics 49, pp. 1161-1187

RUDEBUSCH, Glenn D. 2006. “Monetary policy inertia: fact or fiction?” International Journal of Central Banking Vol.2, No.4

RUDEBUSCH Glenn D. and WU Tao 2008. "A macro-finance model of the term structure, monetary policy and the economy" The Economic Journal 118, pp. 906-926

STOCK, James H. and WATSON, Mark W. 2003. "Has the Business Cycle Changed? Evidence and Explanations" Federal Reserve Bank of Kansas City Symposium, Monetary Policy and Uncertainty pp. 1-47 
TAYLOR, John B. 1993. “Discretion versus policy rules in practice” Carnegie-Rochester Conference Series on Public Policy, 39, pp. 195-214

TAYLOR, John B. 2009. "Economic Policy and the Financial Crisis: An Empirical Analysis of What Went Wrong" Critical Review: A Journal of Politics and Society, 21:2-3, pp. 341-364

TAYLOR, John B. 2010. "Getting Back on Track: Macroeconomic policy lessons from the financial crisis" Federal Reserve Bank of St. Louis Review, May/June 2010, pp. 165-176

TAYLOR, Mark P. and DAVRADAKIS, Emmanuel 2006. "Interest rate setting and inflation targeting: evidence of nonlinear Taylor rule for the United Kingdom" Studies in Nonlinear Dynamics \& Econometrics Vol 10, No. 4, Article 1

WOODFORD, Michael 2003. "Interest and Prices" Princeton University Press, Princeton, NJ.

\section{Internet References}

(Data Sources)

Federal Reserve Bank of St. Louis. (29.09.2014) Available From: http://www.stlouisfed.org/

US Bureau of Labor Statistics. (25.05.2014) Available From: http://www.bls.gov/ 
